Proc. Estonian Acad. Sci. Geol., 2001, 50, 2, 128-134

\title{
LEPISTIKU BURIED PEAT, TALLINN, ESTONIA
}

\author{
Leili SAARSE, Siim VESKI, and Avo MIIDEL
}

\author{
Institute of Geology, Tallinn Technical University, Estonia pst. 7, 10143 Tallinn, Estonia; \\ saarse@gi.ee, veski@gi.ee,miidel@gi.ee
}

Received 10 November 2000, in revised form 23 November 2000

\begin{abstract}
The Lepistiku buried peat section, part of Mustamäe Bog, was studied in Tallinn, North Estonia. It has been a spring-mire, which started to form behind the beach formations about $4700 \mathrm{BP}$ due to land uplift and was situated near the maximum limit of the Litorina Sea (21-22 $\mathrm{m}$ a.s.1.), at an elevation of about 16-17 $\mathrm{m}$ a.s.l. From the beginning of the 19th century, the construction of marine forts and other military objects destroyed the forest cover of the area around the bog and provoked aeolian processes, due to which the southern part of Mustamäe Bog was covered by sand. The aeolian processes lasted up to the 1960s, when Mustamäe housing district was built.
\end{abstract}

Key words: buried organic sediments, radiocarbon dating, Holocene, Tallinn, Estonia.

\section{INTRODUCTION}

Holocene lake and bog sediments are seldom covered by mineral deposits. Such buried organic deposits are important in highlighting the processes triggered off by short geological events, such as the transgression phases in the development of the Baltic Sea. The regressive stages of the Baltic Sea often left behind lakes and lagoons in small depressions, which dried up, paludified, or were covered by terrestrial vegetation, and later, during the following transgressions of the sea, their remnants were inundated and coated by mineral deposits of the coastal formations. In those buried conditions patches of peat and gyttja have been sealed and well preserved up to the present, offering material to accurately date the events involved in the burial process.

The first scientific remarks on the Holocene buried organic deposits in Estonia were provided by Schmidt (1869) and Thomson (1933), followed by Veber (1950), Paas (1960), and others. All the sites discovered by these authors were later studied by Kessel (1962, 1968, 1975; Kessel \& Raukas 1967; Kessel \& Punning 1969a, 1969b, 1974). In the 1960s Kessel described several new sites of 
buried organic matter, most of them found during the exploitation of new gravel pits and proclamation of mires. In 1968 she mentioned 38 sites with buried gyttja and peat at elevations from 5 to $35 \mathrm{~m}$ a.s.l. For now, buried organic deposits of Holocene age are known from 76 sites, 42 of which are connected with the Ancylus Lake beach formations, 27 with the Litorina Sea ones, and 7 are younger and of various age. Very little is known about the organic deposits buried after the Litorina Sea transgression (Künnapuu 1968; Kessel 1975). One of such sites is described in this short note.

\section{MATERIAL}

Buried organic deposits are known from at least four sites within the limits of Tallinn: Iru, Järvevana, Ülemiste, and Mustamäe (Fig. 1a; Künnapuu 1957, 1968). The Lepistiku buried peat locality, part of Mustamäe Bog, was discovered during the construction of a shopping centre at the corner of Sõpruse Avenue and J. Sütiste Road by AS Geotehnika Inseneribüroo (2000).

Mustamäe Bog between A. H. Tammsaare Road and Sõpruse Avenue (Fig. 1b) has an oval configuration, the length in west-east direction being about $2.2 \mathrm{~km}$. The bog is tilted towards the north, where its elevation is $10-12 \mathrm{~m}$ in contrast to the southern 18-20 m (Künnapuu 1968). The thickness of the fen peat in the central part of the bog is about $1-1.5 \mathrm{~m}$ and less than $1 \mathrm{~m}$ in the border areas. Its southern part, about 200-300 m wide, including the Lepistiku site (Fig. 1b,c), is covered by $0.5-3.5 \mathrm{~m}$ thick sand. In January 2000 , when the construction pit was open, the authors of the present paper examined the site more thoroughly. A layer of buried peat with a maximum thickness of c. $1 \mathrm{~m}$ was exposed in the northern cut of the construction pit (Fig. 1d, Photo 1) at an elevation of 16-17 $\mathrm{m}$ a.s.l. The lens of peat faded away in the southern direction. The most representative and longest monolith taken from the vertical cut was sub-sampled at $1 \mathrm{~cm}$ intervals for loss-on-ignition analyses (LOI at low $550^{\circ} \mathrm{C}$ and high $850{ }^{\circ} \mathrm{C}$ temperatures). Additionally, conventional ${ }^{14} \mathrm{C}$ dates were obtained from three $3 \mathrm{~cm}$ slices of sediment.

\section{RESULTS AND DISCUSSION}

Sediment lithology at the sampling point measured from the ground surface was as follows:

0-190 cm Fine-grained sand, the uppermost $40 \mathrm{~cm}$ has slight lamination and has been estimated as filling; 40-190 cm without visible lamination.

190-210 cm Herbaceous peat, well compressed and decomposed. Uncalibrated radiocarbon age of the topmost peat layer $(190-193 \mathrm{~cm})$ is $178 \pm 58$, Tln- 2441 . 

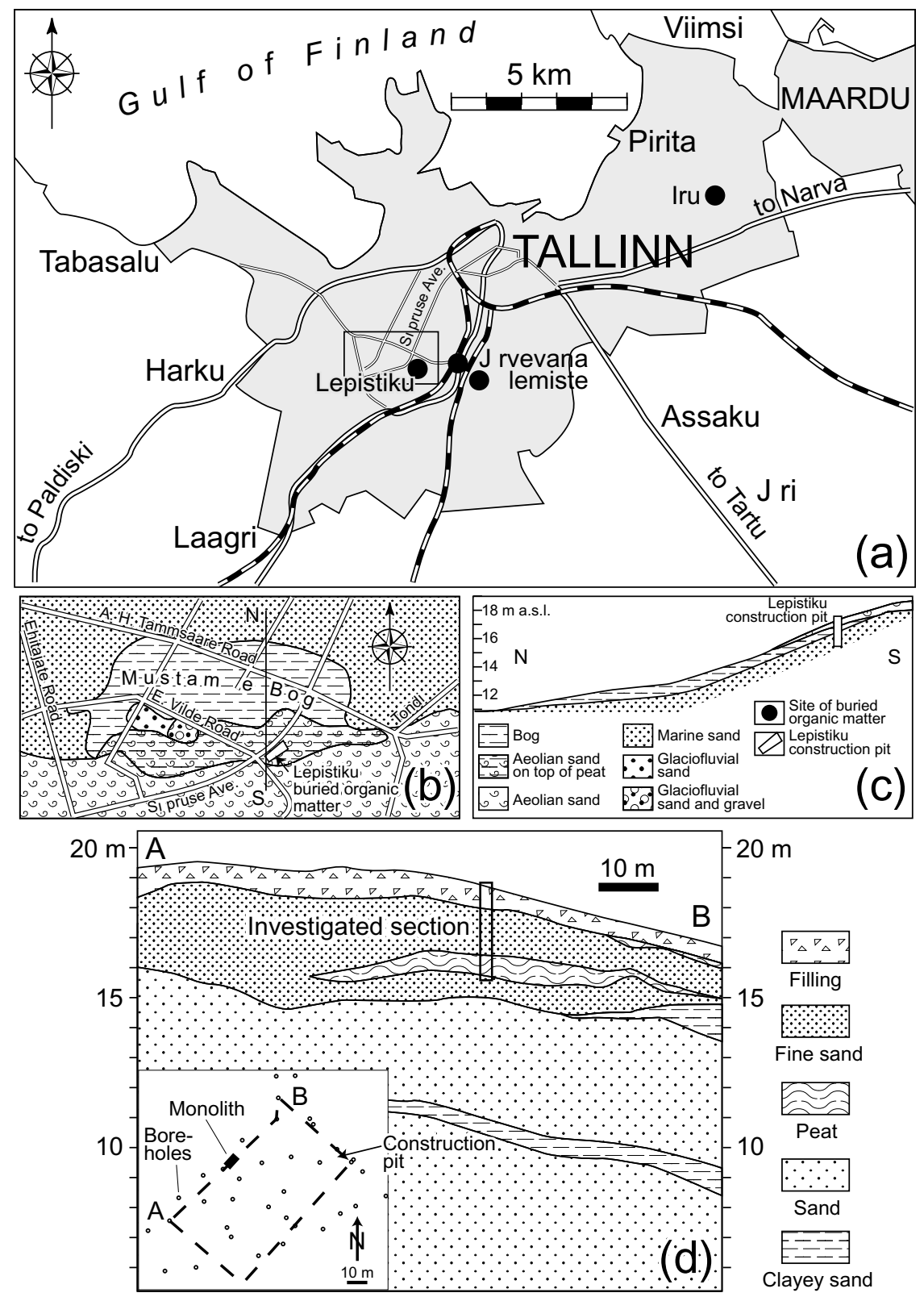

Fig. 1. Location of sites with buried organic deposits in Tallinn: (a) with indication of the Lepistiku site in Mustamäe Bog; (b) the sequence of Mustamäe Bog (after Künnapuu 1968) with authors' modifications; (c) and (d) sampling site at the buried peat sequence at Lepistiku (after AS Geotehnika Inseneribüroo 2000). 


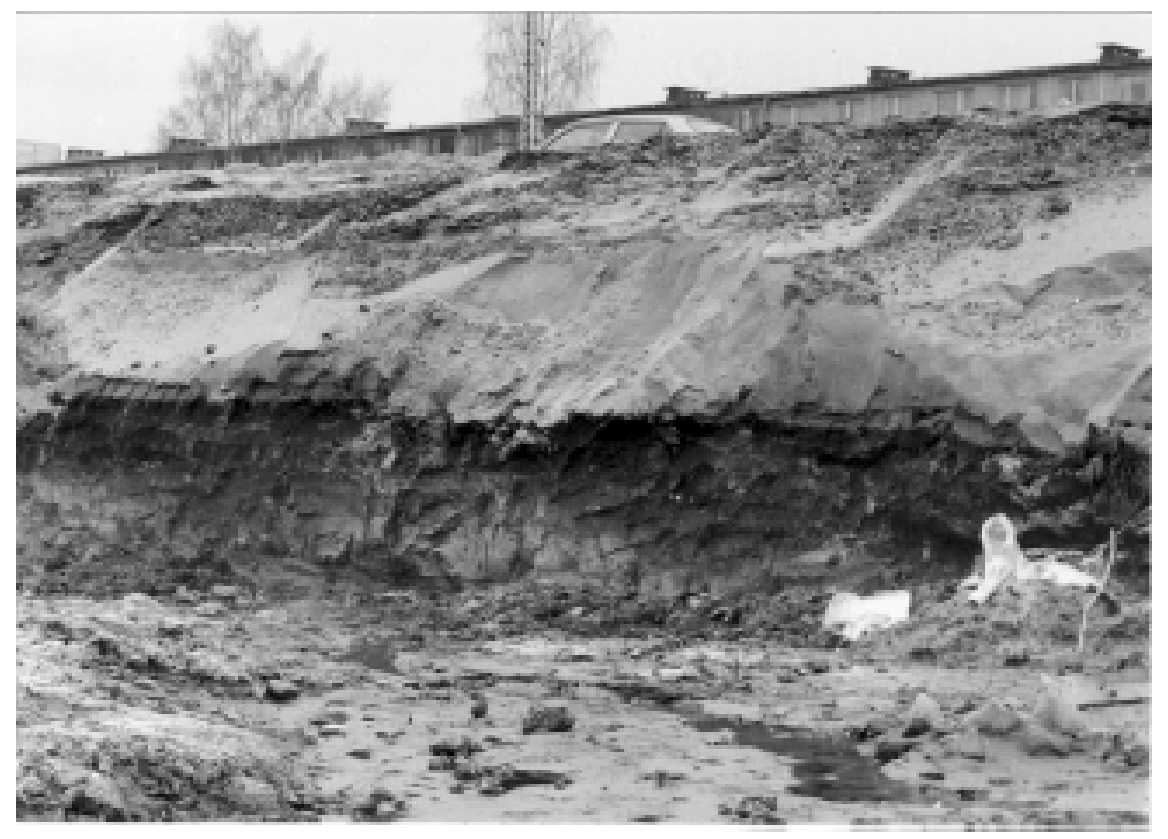

Photo 1. About $1 \mathrm{~m}$ thick peat layer at Lepistiku is buried by $2 \mathrm{~m}$ thick sand. View from south to north, towards Sõpruse Avenue. Photo by A. Miidel, 2000.

210-238 cm Peat with pieces of wood and Phragmites, compressed. Uncalibrated radiocarbon age of the peat from $230-233 \mathrm{~cm}$ is $2790 \pm 60$, Ta-2719.

238-270 cm Peaty gyttja, well decomposed, with single pieces of wood. Uncalibrated radiocarbon age of the peaty gyttja from $250-253 \mathrm{~cm}$ is $3780 \pm 50$, Tln- 2504 .

$270-290 \mathrm{~cm} \quad$ Fine-grained sand with pieces of organic matter.

290-310+ cm Fine-grained sand.

Taking into consideration the retreat of the Ancylus Lake level to $16-18 \mathrm{~m}$ a.s.l. and the elevation of the Litorina Sea transgression to 21-22 m a.s.l. in Tallinn (Kessel \& Raukas 1979), the authors preliminarily concluded that the peat layer was formed before the Litorina Sea transgression and is buried under marine deposits. However, later the ${ }^{14} \mathrm{C}$ dates revealed that this peat layer actually accumulated approximately between 4700 and $180{ }^{14} \mathrm{C}$ years BP, which corresponds to the Sub-Boreal and Sub-Atlantic. The composition of the peat is rather uniform. Loss-on-ignition of the uppermost herbaceous peat varies between 84 and 90\%, LOI in the peat with pieces of wood and Phragmites is 89-92\% (Fig. 2). The carbonate content of the sediment is low. Still, at a depth of $245 \mathrm{~cm}$ it exceeds $3.75 \%$ (Fig. 2). Spring mires at the klint foot are fed by 


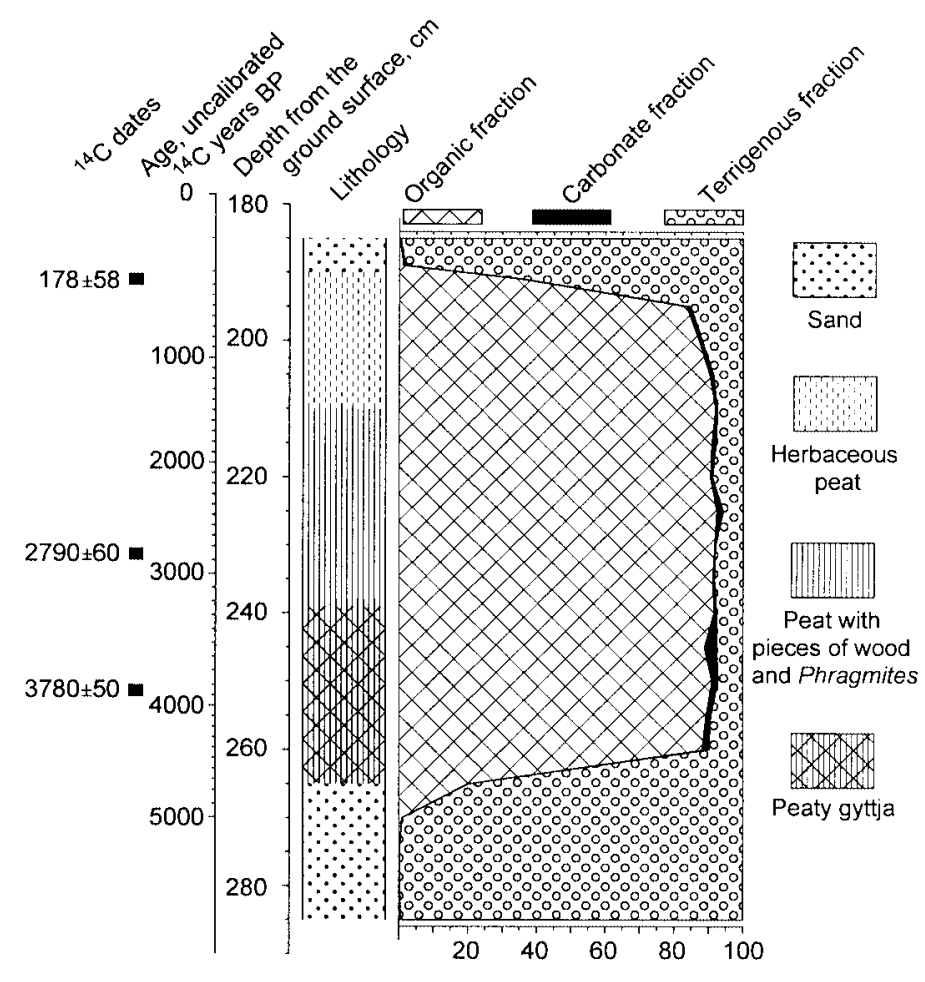

Fig. 2. Composition of the buried peat layer.

springs rather rich in calcareous compounds. The fine-grained sand covering the peat has been interpreted by grain size and sediment structure to be of aeolian origin; the underlying sand contains mollusc fragments and seems to be of marine origin.

The most interesting questions in connection with the accumulation of this peat are: 1) why the peat started to accumulate in the Sub-Boreal which is believed to be a rather dry climatic period, and 2) why the peat bog was covered by sand later? The described buried peat site lies near the Lepistiku black alder grove at the foot of the well pronounced Litorina Sea beach ridges in front of the North Estonian Klint. The klint foreland and Lepistiku alder grove are known for their numerous springs feeding from the Ordovician-Cambrian aquifer at the klint foot. According to the radiocarbon dates and accumulation rate, the springmire started to form about $4700 \mathrm{BP}$, which corresponds to the post-Litorina Sea stage. The shoreline model of the Tallinn area shows that by $4700 \mathrm{BP}$ the postLitorina Sea shore had retreated to c. $15 \mathrm{~m}$ a.s.l., making the peat accumulation at Lepistiku possible. The Limnea Sea beach ridges in the vicinity of Tallinn are located at an elevation of 11-12 m a.s.l. and the sea coast at $4000 \mathrm{BP}$ was about $0.5-1 \mathrm{~km}$ north of the site. The question is: what kind of environmental factors 
caused the formation of the spring mire? A reasonable answer is: the land uplift, due to which the area emerged and the springs, being blocked by beach formations of the post-Litorina Sea or glaciofluvial formations such as along the E. Vilde Road (Fig. 1b), have lost sufficient drainage and started to submerge the area.

The second question is: why the peat was covered by sand? According to the ${ }^{14} \mathrm{C}$ date of the $3 \mathrm{~cm}$ surface layer of the peat, it was buried by sand in very recent, historical times. The process seems to be provoked by human activities. One can think of the clear-cutting and overgrazing of the surrounding sandy area as a sufficient cause to trigger the aeolian processes. A known and more obvious reason can be the construction of marine forts and other military objects to protect the harbour of Tallinn, which started already at the beginning of the 19th century and culminated before the First World War (Gustavson 1993, 1994). Sand was needed for numerous defence constructions and the Litorina Sea beach ridge nearby was a suitable place to excavate it. The area was also cut for timber and cannon shooting-lines cleared. As a result, aeolian processes started in this sandy area to the south and southwest of the mire with a thin soil cover and continued up to the 1960s, when the building of the Mustamäe housing district west of Tallinn began. On the maps from 1899 and 1936 the area around the site of Lepistiku buried peat is shown as a bare open sandy area.

\section{ACKNOWLEDGEMENTS}

This study was supported by the Estonian Science Foundation (grant No. 3621) and governmental target funding (0330358s98). We would like to thank AS Geotehnika Inseneribüroo for their permission to use unpublished geological profiles. Special thanks go to A. Raukas and two referees for valuable suggestions.

\section{REFERENCES}

AS Geotehnika Inseneribüroo 2000. Project 763 - Ehituskrunt Sõpruse pst. 201/203.

Gustavson, H. 1993. Merekindlused Eestis. Olion, Tallinn.

Gustavson, H. 1994. Tallinna vanemad merekindlused. Olion, Tallinn.

Kessel, H. 1962. Balti mere setete alla mattunud organogeensete järve- ja soosetete stratigraafiast Eestis. ENSV TA Geoloogia Instituut. Manuscript. Tallinn, State Archive (R-2346, 3 , 639 ).

Kessel, H. 1968. Mattunud soo- ja järvesetetest. Eesti Loodus, 1, 12-16.

Kessel, H. 1975. Läänemere geoloogiline areng hilisglatsiaalis ja holotseenis Eesti territooriumil. ENSV TA Geoloogia Instituut. Manuscript. Tallinn, State Archive (R-2346, 3, 812).

Kessel, H. \& Punning, J.-M. 1969a. Über das absolute Alter der holozänen Transgressionen der Ostsee in Estland. ENSV TA Toim. Keemia Geol., 18, 140-153 (in Russian).

Kessel, H. \& Punning, J.-M. 1969b. Über die Verbreitung und Stratigraphie der Sedimente des Joldiameeres in Estland. ENSV TA Toim. Keemia Geol., 18, 154-163 (in Russian). 
Kessel, H. \& Punning, J.-M. 1974. About the age of the Ancylus Stage in Estonia (radiometric datings). ENSV TA Toim. Keemia Geol., 23, 59-64 (in Russian).

Kessel, H. \& Raukas, A. 1967. The Deposits of the Ancylus Lake and Littorina Sea in Estonia. Valgus, Tallinn (in Russian).

Kessel, H. \& Raukas, A. 1979. The Quaternary history of the Baltic. Estonia. In The Quaternary History of the Baltic (Gudelis, V. \& Königsson, L.-K., eds.). Acta Univ. Upsaliensis, Symp. Univ. Upsaliensis Annum Quingentesimum Celebrantis, 1, 127-146.

Künnapuu, S. 1957. Pirita jõe alamjooksu oru genees. In Eesti Geograafia Seltsi aastaraamat 1957 (Tarmisto, V., ed.), pp. 74-87. Eesti NSV Teaduste Akadeemia, Tallinn.

Künnapuu, S. 1968. Esialgseid andmeid liivaga kaetud turbalasundite kohta Tallinnas. In Eesti Geograafia Seltsi aastaraamat 1966 (Kildema, K. \& Vabar, M., eds.), pp. 89-105. Valgus, Tallinn.

Paas, A. 1960. Mullastikulisi märkmeid Audru jõgikonna saviliivade alt. Eesti Loodus, 1, 42-46.

Schmidt, F. 1869. Notiz über neuere Untersuchungen im Gebiete der Glacial- und Postglacialformation in Estland und Schweden. In Studien über die Wanderblöcke und die Diluvialgebilde Russlands (von Helmersen, G., ed.). Mem. Acad. Imp. Sci. St.-Pétersb., sér. 7, 14, 55-59.

Thomson, P. W. 1933. Ein von Ancylusstrandbildungen bedecktes Torflager bei Jelgimägi. Beitr. Estl., 18, 176-177.

Veber, K. 1950. Maardu ümbruse geoloogiast. Diploma thesis, Manuscript. Dept. Geol., Univ. Tartu.

\section{MATTUNUD TURVAS TALLINNAS LEPISTIKU PIIRKONNAS}

Leili SAARSE, Siim VESKI ja Avo MIIDEL

On esitatud andmed liiva alla mattunud turba kohta Tallinnas Mustamäel. Turvas hakkas moodustuma umbes 4700 radiosüsiniku aastat tagasi ja ligikaudu 180 aastat tagasi mattus tuiskliiva alla.

\section{ПОГРЕБЕННЫЙ ТОРФ В ЛЕПИСТИКУ, ТАЛЛИНН}

\section{Лейли СААРСЕ, Сийм ВЕСКИ и Аво МИЙДЕЛ}

Представлены данные о занесенном песками торфе в городском районе Мустамяэ. Аккумуляция торфа началась здесь около 4700 лет назад и завершилась примерно 180 лет назад в результате погребения его эоловыми песками. Подробнее проанализированы причины формирования и погребения торфяного слоя. 